\title{
Silicon Induced Drought Tolerance in Crop Plants: Physiological Adaptation Strategies
}

\author{
Krishan K. Verma ${ }^{1} \cdot$ Xiu-Peng Song ${ }^{1}$ - Bo Lin ${ }^{2}$ - Dao-Jun Guo ${ }^{1,3} \cdot$ Munna Singh ${ }^{4}$ - Vishnu D. Rajput ${ }^{5}$. \\ Rajesh Kumar Singh ${ }^{1} \cdot$ Pratiksha Singh ${ }^{1} \cdot$ Anjney Sharma ${ }^{1} \cdot$ Mukesh Kumar Malviya $^{1} \cdot$ Gan-Lin Chen ${ }^{6} \cdot$ Yang-Rui Li $^{1}$ (D)
}

Received: 14 January 2021 / Accepted: 12 March 2021 / Published online: 22 March 2021

(C) Springer Nature B.V. 2021

\section{Introduction}

Water deficiency is a serious abiotic stress that sharply inhibits plant performance of agricultural crops in arid and semi-arid areas globally [1-3]. The water-stressed areas are getting expanded @ 30\% per annum for various reasons viz., by global warming. Thus, increasing crop sufferance to climatic variables are a major factor to overcome declining agricultural foodstuffs producing system and to meet the requirement of nutriment supply for ever-enhancing global populae [3-5]. Globally, it has been evaluated that around $51-82 \%$ of production loss found directly associated with environmental stresses [6].

Silicon $(\mathrm{Si})$ is a ubiquitary constituent and the next most abundant after $\mathrm{O}_{2}$ in soil. It is a major constituent ( $28 \%$ on dry weight basis) of the planet, forming the silicate minerals, i.e. silicate or aluminum silicate, may be differentially absorbed

Krishan K. Verma and Xiu-Peng Song contributed equally to this work.

Yang-Rui Li

liyr@gxaas.net

1 Key Laboratory of Sugarcane Biotechnology and Genetic Improvement (Guangxi), Ministry of Agriculture and Rural Affairs/ Guangxi Key Laboratory of Sugarcane Genetic Improvement/ Sugarcane Research Institute, Guangxi Academy of Agricultural Sciences, Nanning 530 007, Guangxi, China

2 Institute of Agro-Products Processing Science and Technology, Guangxi Academy of Agricultural Sciences, Nanning 530 007, Guangxi, China

3 College of Agriculture, Guangxi University, Nanning 530004, Guangxi, China

4 Department of Botany, University of Lucknow, Lucknow 226007, India

5 Academy of Biology and Biotechnology, Southern Federal University, Rostov-on-Don 344006, Russia

6 Institute of Biotechnology, Guangxi Academy of Agricultural Sciences, Nanning 530 007, Guangxi, China by the plants [7-9]. The significance of Si for agro-ecosystems has been the topic of discussion [10-13]. Since the Pioneer workers as Sprengel and van Liebig in the initially to middle-1800s [14], and the rectified by Arnon and Stout [15], plant physiologist/ ecologist have updated the rejection of $\mathrm{Si}$ from the catalog of key mineral nutrients for vascular plants $[16,17]$. The application of silicate on plants initiated in 1950s in Japan, and by now it is frequently used in various regions of the globe [18-20]. The plants have been categories on the base of their Si accumulation levels, and recognized as minimum, medium and maximum accumulators $[9,21]$.

The International Conference on Silicon in Agriculture (ICSA) is only silicon conference of its kind that is created to discuss/ presented updated developments, significant issues of the application of Silicon in agro-ecosystems. The ICSA is held on a triennial basis around the globe. Originating in Florida, United States (1999), then Tsuruoka, Japan (2002), Uberlandia, Brazil (2005), Durban, South Africa (2008), Beijing, China (2011), Stockholm, Sweden (2014) and Bangaluru, India (2017) have been successfully held to understand the role of Si application linked with plant productivity under various environmental stresses. Further, ICSA was proposed in New Orleans, Louisiana, USA (2020), cancelled due to coronavirus outbreak, and rescheduled in May 23-26, 2022.

In this chapter, the recent and updated development of silicon role in plant resilience to drought stress and the underlying mechanisms and/or functions have been compiled to reveal the role of Si to enhance crop productivity under arid and semi-arid agroclimatic cropping zones (Fig. 1).

\section{Silicon Improves Photosynthetic Efficiency under Water Stress Condition}

The exchange of leaf gas is a fundamental process in chloroplasts that results in the transformation of sunlight into energy 


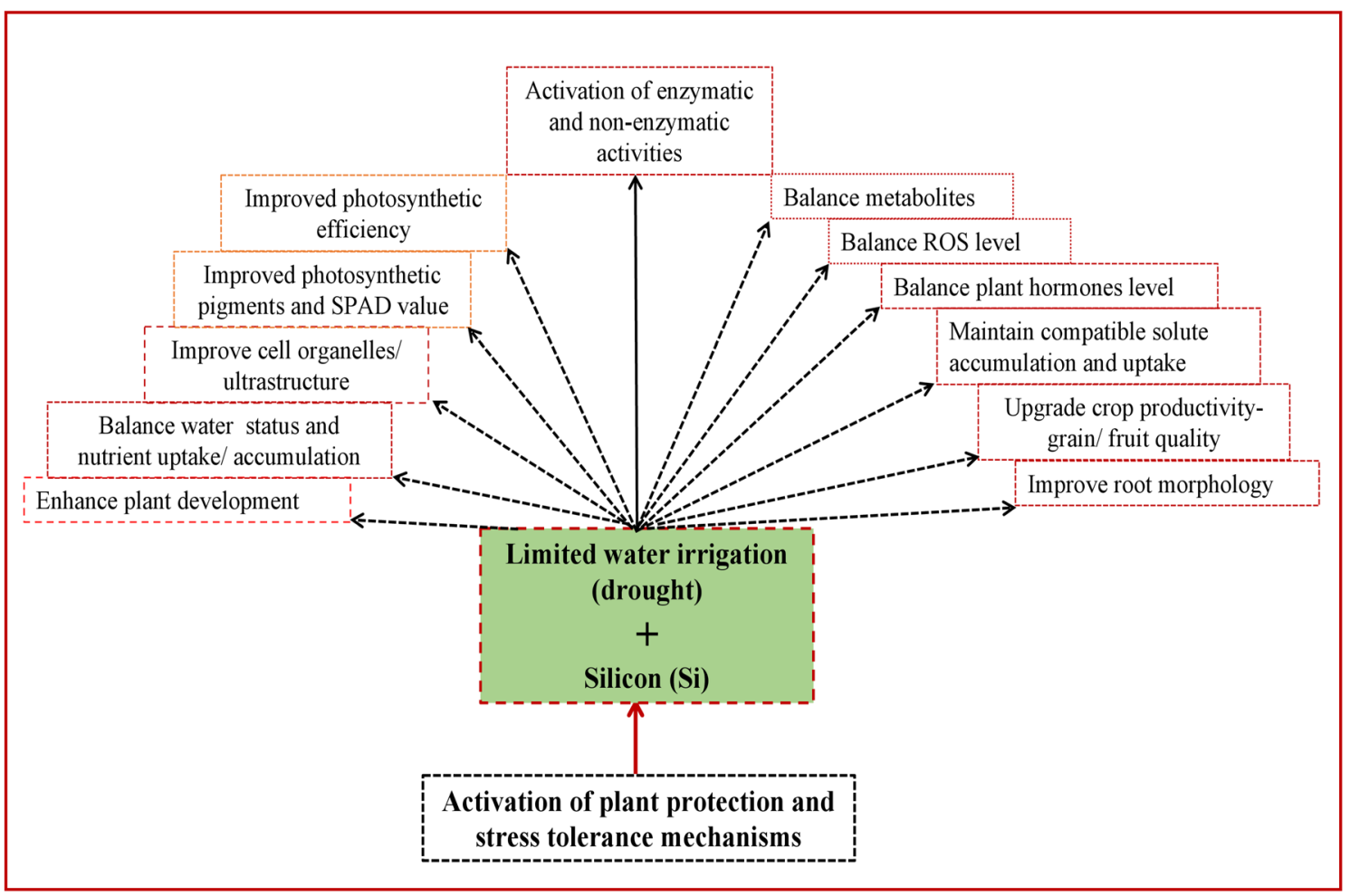

Fig. 1 Impact of silicon with plant tolerance functions and/or mechanisms subjected to limited water irrigation

to power the biochemical activities of plants [22, 23]. Growth and development of plants are mostly depends on photosynthetic efficiency. Photosynthetic capacity is down-regulated under stress conditions [2, 24], and exogenous application of $\mathrm{Si}$ has been found to improve this reduction and thus sustain normal growth and development of plants subjected to drought-stressed plants. Gong et al. [25] and Verma et al. [2] noted that under limited irrigation, $\mathrm{Si}$ in Triticum and Saccharum spp. had conferred maximum photosynthetic efficiency. The similar findings were assessed in Sorghum [26, 27] and rice plants [28]. The photosynthesis of sorghum and sugarcane in water stress conditions were improved, incase $\mathrm{Si}$ applied which resulted in highest dry biomass exposed to stress conditions $[3,26]$. The stomatal and non-stomatal limitations have been due to the reduction in photosynthetic responses during water stress [29]. Stomatal closure is the initial reaction of plants under extreme drought stress, and is commonly considered to be the key limiting factor for the exchange of leaf gas [30-32]. Although stomatal closure normally occurs during unfavorable atmospheric variables, nonstomatal limitations, such as decreased carbon fixation ability by chloroplast can down-regulate photosynthetic efficiency under stress as well.

Chen et al. [28] indicated that Si-mediated enhancement of leaf gas exchange ability in Oryza sativa plants during water-stressed was correlated with stomatal and nonstomatal variables. Gong and Chen [33] and Verma et al. [34] demonstrated the diurnal variations of photosynthetic traits in wheat and sugarcane plants subjected to water stressed conditions with loss in stomatal conductance. However, Si enhanced the photosynthetic efficiency during day time. In the daily cycle, Si amendment also enhanced the stomatal conductance during water stress. These observations suggested that stomatal and non-stomatal variables were associated in the maintenance of photosynthetic $\mathrm{CO}_{2}$ assimilation by Si. Ming et al. [34] and Verma et al. [2] demonstrated that Oryza and Saccharum spp. both enhanced transpiration incase $\mathrm{Si}$ application safe and subjecting to drought stress. Several other results on water-stressed plants have been reported by $\mathrm{Si}$ amendment to be consistent with increased leaf transpiration [3, 26-28, 33, 34, 36-42] Verma et al., 2021) (Figs. 1 and 3; Table 2).

Photosynthetic pigments play an important role in the ability to photosynthesize and are responsible for complex light harvesting. Lobato et al. [43] and Verma et al. [2, 41] explored that the use of $\mathrm{Si}$ could increase the quality of chlorophyll in Capsicum annuum and Saccharum spp. during drought, indicating that Si may mitigate stress-induced damage to the photosynthetic machinery and thus sustains the leaf gas exchange. According to Yin et al. [44], Si-mediated increase in polyamine synthesis and enhancement of chlorophyll content was noted, indicating that polyamines are involved in improving the overall photosynthetic pigment content and thus delaying leaf senescence. Applied Si not only improved the content of chlorophyll, but also enhanced the ratio of chlorophyll a/b, showing the level of thylakoid stacking $[9,45]$. 
Leaf chlorophyll fluorescence variables may provide useful tools for plant photosystem II (PS II) activity, and PSII photochemistry's minimum and maximum quantum efficiency are linked to photosynthetic capacity $[3,46]$. Amendment of Si not only enhanced the chlorophyll content but also enhanced ration of $F v / F_{0}$ and $F v / f m$ in Oryza sativa and Saccharum spp. during water stressed [2, 28, 41]. The Si amendment increased the activity of RuBisCO in hydroponically grown cucumbers [47]. Gong and Chen [33] observed that in water-stressed plants, the concentration of inorganic phosphorus in Triticum aestivum leaves was reduced while it was upregulated by applying Si. Improving the inorganic phosphorus content will promote the synthesis of ATP needed in the $\mathrm{CO}_{2}$ assimilation cycle [48]. In photosynthetic reactions, more work is needed to disclose the significant of $\mathrm{Si}$ because very little is known on Si's role in diurnal variations in plant photosynthetic efficiency [34].

\section{Role of Silicon for Plant Growth Enhancement and Nutrients Uptake}

In addition to improved photosynthetic assimilation rate, the improvement/maintenance of plant growth and development through the application of Si during abiotic stresses may be linked to nutrient uptake. Drought stress and other abiotic stresses limit the absorption by plant roots of essential nutrients and their transport to leaf shoots and thus reduce the supply of nutrients [2, 31, 49]. In improving/maintaining the absorption, transport and allocation of mineral nutrients in stressed plants (Fig. 3). Silicon also plays an important role and thus increases plant output in unfavorable environmental variables. The Si amendment was observed in the Zea mays leaves to increase the $\mathrm{Ca}$ and $\mathrm{K}$ content [49]. Improved uptake of $\mathrm{Ca}$ and $\mathrm{K}$ during abiotic stresses could also lead to stress tolerance. The reduction in plasma membrane permeability and up-regulation of plasma membrane $\mathrm{H}+$-ATP activity in Si-applied plants may extend plant performance [32, 49, 50].

Detmann et al. [51] demonstrated that Si could enhance the productivity of rice grains and the efficiency of $\mathrm{N}$ use. More scientific research is therefore needed to determine how Si controls the absorption of $\mathrm{P}$ and $\mathrm{N}$ and what factors influence the efficacy of Si. Nutrient uptake is associated with root growth, morphological traits such as diameter, area, volume, root dry bulk, total and main root length [52-54]. The significant role of $\mathrm{Si}$ on root development during stress have been noted in few studies because stress may condition, reduce shoot/root ratio and maximum accumulation of root dry biomass in sorghum [26]. The root growth stimulation by Si application may be correlated with root elongation by increasing the extensibility of cell walls in the sorghum growing area [55].
Water and essential mineral elements are absorb by the plant roots, water stressed plants can have a harmful effect on plant growth, development by proper root development $[41,56]$. An increment in the plant root's morphological traits provides additional exposed areas for the absorption of diffusible ions [56, 57]. Increased root growth caused by the application of $\mathrm{Si}$ has also been documented in various drought studies [53, 54, 58]. The up-regulated root/shoot ratio in $\mathrm{Si}$-applied plants suggests that $\mathrm{Si}$-mediated root ultrastructure modifications can also account for $\mathrm{Si}$ applied plants' increased water uptake capability [36] (Figs. 1 and 2).

\section{Silicon Contributes to Maintaining Plant Water Balance}

During favorable situation, water is absorbed by the plant roots and reduced from the plant leaves, and plants maintain natural water balance by constantly changing these processes $[32,59]$. Plants have a particular technique to improve and/or balance of water when conditions are unfavorable [60]. Drought stressed conditions, the first reaction of the plants to prevent low water potential by changing its water balance between root water absorption in leaf water $[9,61,62]$. Plants may decrease loss of leaf water by regulating the transpiration rate and also by reducing their leaf area-expansion. The Si amendment may enhance/ balance water status in stressed plants. Silicon could enhance the water potential of leaves in plants subjected to water-stressed [27, 63, 64]. The rate of transpiration may affect plant water relationships $[2,31]$. Plants mainly transpired by leaves, via the cuticle and stomata. The significant role of $\mathrm{Si}$ in plant development and water retention has long been linked to the mitigation of abiotic stresses. Several studies have well recorded the improvement of leaf stomatal conductance, transpiration rate, leaf water content (LWC) and root and whole plant hydraulic conductance by plants irrigated with Si $[3,65,66]$ (Figs. 2 and 3; Table 2). The hydraulic conductivity of the roots mainly depends on the capacity of water absorption and root anatomypermeability and driving force [67]. The status of water in leaf is determined by the absorption and uptake of water, i.e. the loss of transpirational water [68]. The variation in transpiration rate is different mechanism by which plants may regulate water status $[32,69]$.

The findings indicated that $\mathrm{Si}$ was correlated with stomatal movement control. The decrease in transpiration from the cuticles or stomata may be associated with the conditions of plant species/cultivars or culture. However, application of $\mathrm{Si}$ does not always reduce the rate of plant transpiration. Hattori et al. [26] and Verma et al. [2] evaluated Si application during water-stressed conditions to improve stomatal conductance 

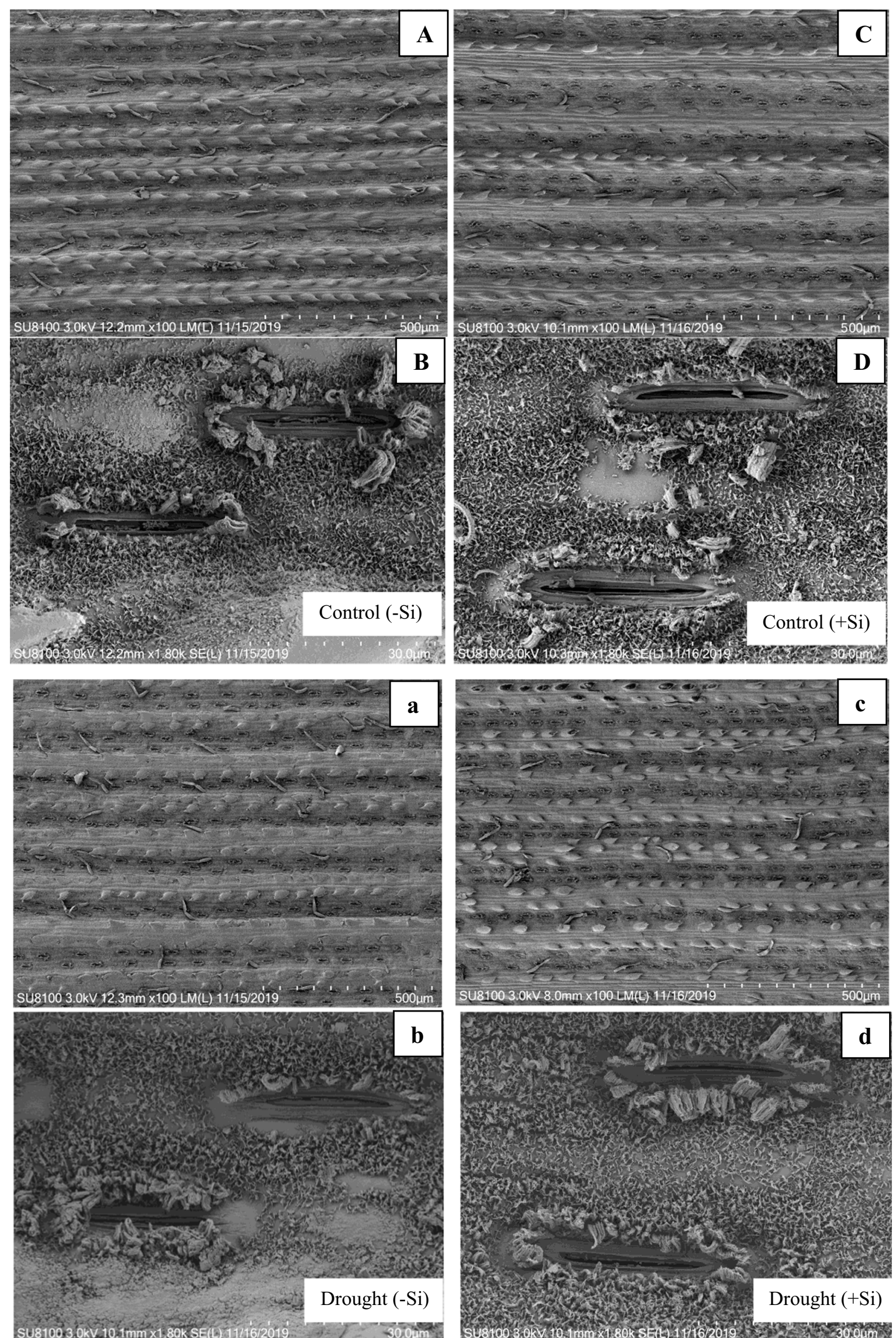
Fig. 2 Stomatal aperture in the leaves of sugarcane plants grown in well water (90-85\% FC, control, A-D) and limited irrigation (50-45\% FC, drought, a-d) with or without silicon application (500 ppm), respectively. The scale bars of the micrographs are 30 and $500 \mu \mathrm{m}$, respectively

and transpiration rate of plant leaves in sorghum and sugarcane. Stressed wheat [25, 63], rice [28] and sugarcane [41] were also found to have similar findings. In order to understand how and if Si regulates stomatal movement and what potential factors are involved, further studies are required. Another potential reason may be correlated with growth conditions, such as soil or solution culture, for the differences in transpiration rate [70]. Plants typically enhance root length and/or root area to achieve better access to water. The roots are still in contact with water, and plants need to adjust by increasing their internal hydraulic conductivity to drought stress $[9,28,70]$.

\section{Silicon Enhances Root Water Uptake during Water Stress Condition}

In addition to leaf transpiration, the close relationship between transpiration rate and Si suggests that there may be some mechanisms that linked to Si-mediated avoidance to abiotic stresses. Water root uptake is a very critical process that improves the balance of water in crop plants. Silicon can influence the growth and development of roots and thus regulate water relations. The amendment of Si enhanced the root development during stress $[2,28]$. Si-mediated increment in root area zone have also been monitored in sorghum and sugarcane subjected to water-stressed plants $[3,44]$. The development of root was correlated with root plasticity modulation, which has been regulated by Si-mediated enhance in polyamine and reduce ethylene contents. The improved root area may increase the absorption of water, which helps to enhance the avoidance of water stress by plants. The

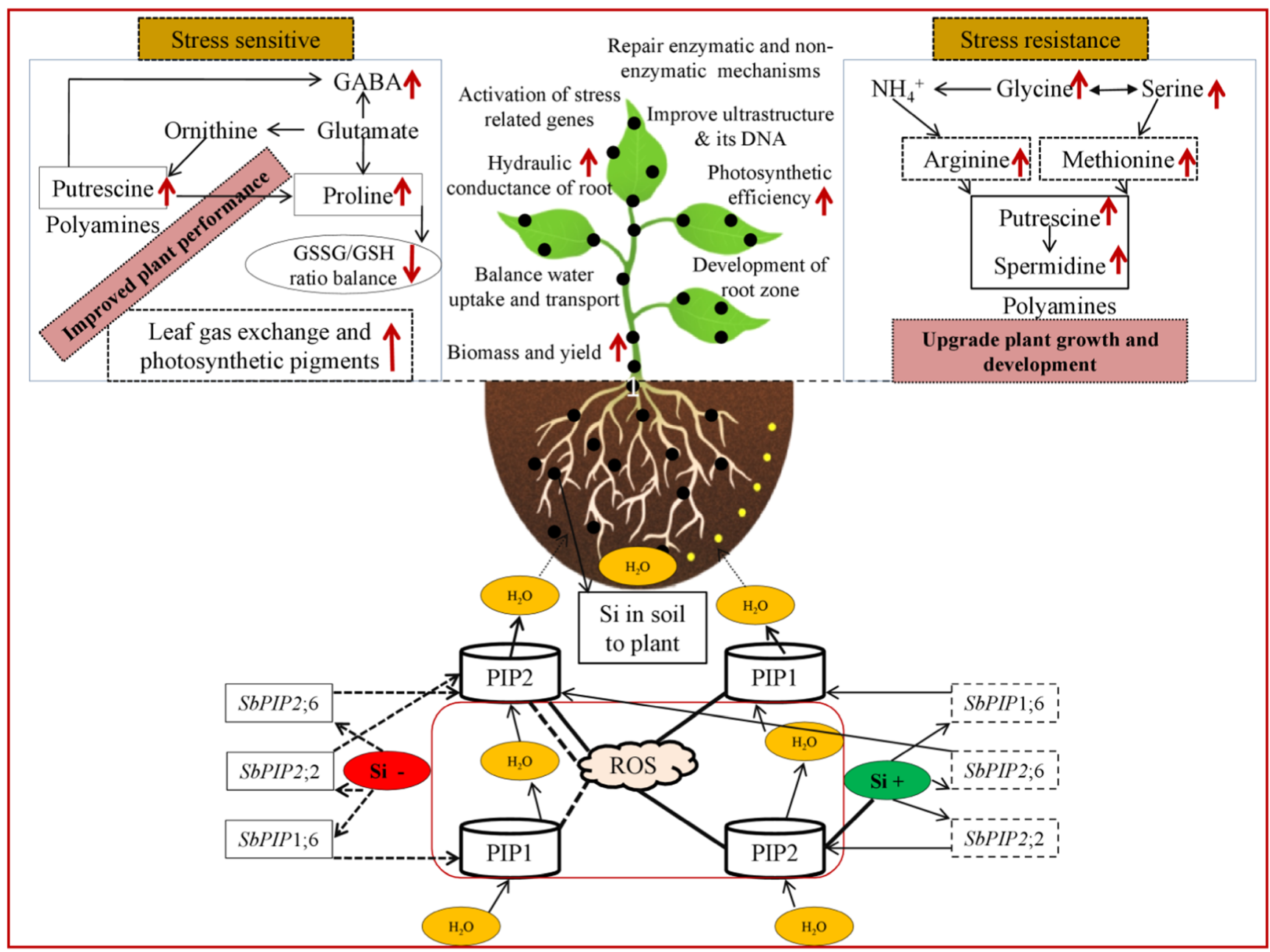

Fig. 3 Potential strategies for Si mediated water balance of plants subjecting water deficit. Silicon upregulating the activity of aquaporin by the expression of PIP - Plasma membrane Intrinsic Protein aquaporin genes and mitigating the ROS - reactive oxygen species induced aquaporin activity inhibition. The role of higher root hydraulic conductance enhanced the uptake and transport of water, which promote to maintain maximum leaf photosynthetic efficiency and improve plant tolerance to stressed condition. The proposed model mechanism was conceived based from the following literature $[2,32,42,66,72,89$, 90]. Dotted and line arrows indicate down-regulation and upregulation of genes (with Si application). SbPIP - Sorghum Plasma membrane intrinsic protein 
significant observation was noted in shoot development [23, 71]. The cucumber plants has also been monitored for similar results [70]. Drought stress enhanced the root hydraulic resistance to the flow of water, which was significantly reduced by the application of silicon in sorghum [72].

During drought stress, osmotic adaptation plays a major role in the uptake of root water [73]. The Si amendment decreased the osmotic potential of the roots and increased the relative content of leaf water, indicating that the role of osmotic adjustment in the absorption of root water in Si-applied plants [36]. In Oryza sativa, Si-induced improved water status and accumulation of soluble sugars in plant roots [74, 75]. Proline is one of the major compatible solutes normally accumulated during stress and plays a significant role in osmotic adjustment $[64,76,77]$. Compatible solutes or osmolytes increase primarily proline, glycine betaine and polyols in plants during stress, i.e. drought [64, 77-79]. By stabilizing proteins and their complexes, as well as membranes during abiotic stresses, the above compounds can mitigate the limiting factor of raising the maximum ion content of enzyme activities [8]. There are various scientific reports that Si fertilizer may also boost plant resistance to water deficit by changing the content of solutes, i.e. proline $[2,65,80]$, glycine betaine [81], carbohydrates [35], polyols, antioxidant compounds such as total phenolics [82], soluble sugars and free amino acids [36, 83] (Table 1).

Pei et al. [64] and Verma et al. [2] showed that the proline level was enhanced during drought in Triticum aestivum and
Saccharum spp. leaves, while the use of Si reduced its accumulation, implying that proline accumulation was a sign of injury to stress. The improvement of osmotic adjustment in terms of osmolytes enhancement through the application of $\mathrm{Si}[32,37]$. Aquaporins are significant facilitators of water transport in plants for root water absorption $[84,85]$. Aquaporins can be subdivided into various subfamilies such as PIPs - intrinsic plasma membrane proteins, TIPs - intrinsic tonoplast proteins, SIPs - small basic intrinsic proteins, NIPs - intrinsic nodulin26-like proteins and XIPs - uncharacterized X intrinsic proteins [86]. PIPs and TIPs represent the core pathway of water transport between and within cells among these aquaporins $[9,32,84]$. The Si amendment could boost root hydraulic conductance and induce the enhancement of PIP gene expressions during drought in sorghum plant, suggesting that $\mathrm{Si}$ regulating water uptake during stressed (Fig. 3; Table 1). Silicon may influence the formation of casparian bands in plant roots [32, 87, 88]. Little information is available on the relationship between $\mathrm{Si}$ and the metabolism of compatible solutes and the absorption of water in plants, and further research is expected in the near future.

\section{Role of Silicon on the Integrity, Stability and Functions of Membranes}

The primary targets of abiotic stresses include plant cell membranes such as plasma and endomembrane [9, 91]. The balance/maintenance of membrane cell integrity is essential
Table 1 Role of gene expression upon the application of $\mathrm{Si}$ subjected to stress condition

\begin{tabular}{llll}
\hline Plant & Functional annotation & Mechanism & Reference \\
\hline Rice & Subunit of oxygen evolving complex-PSII & Photosynthesis & {$[99]$} \\
Rice & Photosynthetic co8y stability maintenance & Photosynthesis & {$[99]$} \\
Rice & Maintenance of cytochrome & Photosynthesis & {$[99]$} \\
Rice & Ferrodoxin NADP+ reductase & Photosynthesis & {$[99]$} \\
Rice & Subunit of LHC II complex & Photosynthesis & {$[99]$} \\
Rice & Subunit of LHC II complex & Photosynthesis & {$[99]$} \\
Rice & Member of RING domain containing protein family & Regulatory gene & {$[100]$} \\
Rice & Dehydration responsive element binding protein & Regulatory gene & {$[100]$} \\
Rice & Choline monooxygenase & Regulatory gene & {$[100]$} \\
Rice & NAC regulons (No apical meristem(NAM), Arabidopsis & Regulatory gene & {$[100]$} \\
& thaliana activating factor [ATAF], and cup-shaped & & \\
& cotyledon [CUC]) & & {$[100]$} \\
Rice & Dehydrin & Regulatory gene & {$[101]$} \\
Sorghum & S-Adenosyl-L-methionine decarboxylase & Polyamine synthesis & {$[101]$} \\
Sorghum & S-Adenosyl-Metdecarboxylase & Polyamine synthesis & {$[101]$} \\
Sorghum & S-Adenosyl-Metdecarboxylase & Polyamine synthesis & {$[101]$} \\
Sorghum & Arginine decarboxylase & Polyamine synthesis & {$[101]$} \\
Sorghum & N-Carbamoyl putrescine amidohydrolase & Polyamine synthesis & {$[101]$} \\
Arabidopsis & Esterase lipase thioesterase family protein & Transporter gene & {$[102]$} \\
Arabidopsis & Copper transporter & Transporter gene & {$[102]$} \\
\hline & & & \\
\hline
\end{tabular}


for the growth of plants in unfavorable environmental variables. The leakage (EC) of electrolytes from the cell has long been used as a symbol of membrane damage. The Si amendment indicated to reduce the EC level in Oryza sativa, Glycine max and Triticum aestivum during water-deficit conditions $[64,91,92]$, showing the defensive role of Si against membrane damage. Silicon effects the changes of cell morphology in wheat during water-stress [93]. The thylakoids were swollen in chloroplast, and the matrix lamella seemed to be degraded/damaged; this resulted in a decrease in plasmolysis when Si was fed to the plants and upgraded the ultrastructure of chloroplast. The leaf ultrastructure was also upgraded in the Si-applied plants (Figs. 2 and 3) cultivated during water stress $[2,35]$. For the function of the cell membranes, fluidity is a simple and important parameter.

Huang and Yang [94] demonstrated that the balance fluidity in the mitochondrial membrane was important to maintain its structure. However, little information is available on the role of $\mathrm{Si}$ in the fluidity of the membrane in plants during stress. Membrane fluidity is depends on various factors, i.e. interactions of proteins, lipids and lipid composition [9, 32, $94,95]$. Si was shown in strawberry plants to increase the amount of membrane lipids during control conditions with Si application [96]. Therefore, there is a possibility that the amended Si enhanced the contents of phospholipids and proteins both, with a greater increase of the latter. A downregulation in fatty acid unsaturation is generally considered to result in a decrease in membrane fluidity [97]. Si enhanced the unsaturation of fatty acids, which was reduced during water-deficit condition [25]. The upregulation of plasma membrane $\mathrm{H}+-\mathrm{ATPase}$ activity by $\mathrm{Si}$ can also lead to enhance uptake of nutrients during stress as discussed previously [28, 49, 64, 90].

The various strategies of Si-mediated stress mitigation, the primary stress-combating mechanisms utilized by $\mathrm{Si}$ is the maintenance of photosynthetic process in the stressed plants. Even though, several demonstrations have evidenced the potential role of $\mathrm{Si}$ on leaf gas exchange, only a little have assessed the molecular mechanism behind the expression of genes upon Si application [33, 77, 90, 98-101]. The physiological improvement of photosynthetic mechanisms and loss in the degradation of photosynthetic pigments documented by various pioneer workers can be linked with the genic regulation of photosynthetic genes by $\mathrm{Si}$ at molecular basis (Table 1).

$\mathrm{Si}$ had no effect on the plasma membrane $\mathrm{H}+$-ATPase in field conditions, indicating that $\mathrm{Si}$ effect on membrane fluidity and enzyme activity could be secondary [103]. Si in Oryza sativa plants significantly increased the polysaccharide content in the leaves $[32,91]$. Si also affects other components of the cell wall, including pectic acid, protein, polyphenols and lignin $[9,87,104,105]$. These results indicated that $\mathrm{Si}$ is involved in the biosynthesis of components of the cell wall, thereby influencing the mechanical properties of the cell walls and, consequently, their water permeability. The effects of $\mathrm{Si}$ on the properties of the cell wall can in turn affect the properties of the membrane $[32,91]$; this needs to be confirmed by mechanistic experiments, however. The enhanced antioxidant defense mechanism is also interconnected with Simediated balance/improvement in membrane integrity and stability in stressed plants.

\section{Regulation of Antioxidant Enzymes}

The degree of drought tolerance varies from species to species and also from different genotypes, whereas there will be differences in the individual plants of the same cultivars. By completely distorting the control mechanism, the plant water deficit will adversely affect the electron transport chain (ETC) in mitochondria and chloroplasts [106]. One of the immediate effects of developing reactive oxygen species (ROS) on water stressed plants. ROS is a potent oxidizing compound that can damage the functions of the plasma membrane and endomembrane [107]. Developed a complex antioxidant machinery to improve/ balance homeostasis through enzymatic and non-enzymatic antioxidants such as superoxide dismutase (SOD), peroxidase (POD), catalsae (CAT), ascorbate peroxidase (APx), dehydroascorbate reductase (DAR), guaiacol peroxidase (GPOD), glutathione reductase (GR) and carotenoids, non-protein amino acids, phenolic compounds tocopherols, ascorbate and glutathione are one of the strategies to mitigate and restore the damage caused by ROS in plants [2, 41, 58, 108]. Si can also minimize oxidative damage in plants during stress by regulating the antioxidant machinery of the plants [8, 108]. Oxidative damage during water-stressed conditions due to overproduction of ROS is also mitigated by exogenous Si application. The foliar spray of Si upregulated the SOD level in barley, tomato and sugarcane $[3,63,68,77]$ especially in low available water in soil content [109]. The amendment of Si enhanced the level of SOD and reduced POD activity in barley crop at the rain filling stage [63] of water-deficit plants. Silicon significantly enhanced the glutathione level in wheat leaves subjected to drought, presumably due to enhanced GR activity (Table 2).

One of the most destructive processes in living organisms is ROS-induced oxidation of functional molecules such as lipids, proteins, etc. [9, 29, 110]. Different demonstrations have shown that the avoidance of Si-mediated plants toward environmental stresses, i.e. salinity and heavy metal stress, is correlated with decreased oxidative damage of cell functional molecules. The amendment of Si enhanced the photosynthetic pigments and protein levels in stressed wheat and sugarcane 
Table 2 The role of Si on plant stress tolerance mechanisms in variety of plants subjected to limited water irrigation

\begin{tabular}{|c|c|c|c|c|c|}
\hline Plants & Source of Si & $\begin{array}{l}\text { Treatment } \\
\text { condition }\end{array}$ & Variables & Response & Reference \\
\hline $\begin{array}{l}\text { Tomatao } \\
\text { (Solamum lycopersicum } \\
\text { L.) }\end{array}$ & $\begin{array}{l}\text { Sodium silicate and } \\
\text { Potassium silicate }\end{array}$ & Hydroponic & $\begin{array}{l}\text { Growth traits } \\
\text { Chlorophyll content } \\
\text { Photosynthetic efficiency }\left(P_{N}, E, g s\right) \\
\text { Leaf relative water content }(\%) \\
\text { Relative electrolyte leakage (EC, \%) } \\
\text { Root hydraulic conductance } \\
\text { Sulfur and Ammonium content } \\
\text { Glycine, GABA, Arginine, Alanine, Methionine, } \\
\text { Serine, Putrescine and Spermine content } \\
\text { Glutamic, proline and malondialdehyde content } \\
\text { Antioxidant enzyme activities } \\
\text { Gene expression levels } \\
\text { Plasma membrane aquaporin genes } \\
\text { Reactive oxygen species (ROS) }\end{array}$ & $\begin{array}{l}+ \\
+ \\
+ \\
+ \\
- \\
+ \\
+ \\
+ \\
- \\
+ \\
+ \\
\text { no } \\
\text { change }\end{array}$ & {$[68,77]$} \\
\hline $\begin{array}{l}\text { Sorghum (Sorghum } \\
\quad \text { bicolor (L.) Munch) }\end{array}$ & Potassium silicate & $\begin{array}{l}\text { Soil and } \\
\text { hydroponic } \\
\text { culture }\end{array}$ & $\begin{array}{l}\text { Growth \& biomass attributes } \\
\text { Relative growth rate (RGR) } \\
\text { Net assimilation rate (NAR) } \\
\text { Leaf area index (LAI) and ratio } \\
\text { Leaf chlorophyll index } \\
\text { Photosynthesis }\left(P_{N}\right) \\
\text { Transpiration (E) } \\
\text { Stomatal conductance (gs) } \\
\text { Intercellular } \mathrm{CO}_{2} \text { level (Ci) } \\
\text { Water use efficiency (WUE) } \\
\text { Root water uptake } \\
\text { Silicon uptake } \\
\text { Leaf and soil water potential }\end{array}$ & $\begin{array}{l}+ \\
+ \\
+ \\
+ \\
+ \\
+ \\
+ \\
+ \\
- \\
- \\
+ \\
+ \\
+\end{array}$ & $\begin{array}{c}{[26,36} \\
122]\end{array}$ \\
\hline $\begin{array}{l}\text { Straberry } \\
\quad \text { (Fragaria*ananassa } \\
\quad \text { 'Camarosa') }\end{array}$ & Potassium silicate & Soil culture & $\begin{array}{l}\text { Growth variables } \\
\text { Chlorophyll content } \\
\text { Chlorophyll fluorescence variables }(\mathrm{Fv} / \mathrm{Fm}) \\
\text { Leaf gas exchange } \\
\left(P_{N}, E \text {, gs) }\right. \\
\text { Membrane injury }(\mathrm{EC}, \%) \\
\text { Proline content }\end{array}$ & $\begin{array}{l}+ \\
+ \\
+ \\
+\end{array}$ & [123] \\
\hline Maize (Zea mays L.) & $\begin{array}{l}\text { Sodium silicate and } \\
\text { Calcium silicate }\end{array}$ & Soil culture & $\begin{array}{l}\text { Growth and Biomass/ productivity } \\
\text { Leaf relative water content (LRWC, \%) } \\
\text { Photosynthetic pigments }(\mathrm{Chl} \mathrm{a}, \mathrm{Chl} \mathrm{b} \& \mathrm{Chl} \mathrm{a+b)} \\
\text { Photosynthetic capacity }\left(P_{N}, E, g s\right) \\
\text { Electrolyte leakage }(\mathrm{EC}, \%) \\
\text { Proline level } \\
\text { Calcium, potassium and silicon ion uptake }\end{array}$ & $\begin{array}{l}+ \\
+ \\
+ \\
+ \\
- \\
- \\
+\end{array}$ & $\begin{array}{c}{[49,124} \\
125]\end{array}$ \\
\hline $\begin{array}{l}\text { Wheat (Tritium aestivum } \\
\text { L.) }\end{array}$ & Sodium silicate & Soil culture & $\begin{array}{l}\text { Growth capacity } \\
\text { Chlorophyll content (Chl a, b \& a+b) } \\
\text { Water utilization efficiency (WUE) } \\
\text { Leaf relative water content (LRWC, \%) } \\
\text { Chlorophyll content (Chl a, b \& a+b) and Chlorophyll } \\
\text { stability index (CSI) } \\
\text { Leaf chlorophyll fluorescence variables } \\
\text { Antioxidative enzymes }\end{array}$ & $\begin{array}{l}+ \\
+ \\
+ \\
+ \\
+\end{array}$ & {$[53,126]$} \\
\hline
\end{tabular}


Table 2 (continued)

\begin{tabular}{|c|c|c|c|c|c|}
\hline Plants & Source of Si & $\begin{array}{l}\text { Treatment } \\
\text { condition }\end{array}$ & Variables & Response & Reference \\
\hline Rice (Oryza sativa L.) & Calcium silicate & Soil culture & $\begin{array}{l}\text { Growth traits } \\
\text { Proline } \\
\text { Peroxidase activity (POD) }\end{array}$ & $\begin{array}{l}+ \\
- \\
+\end{array}$ & {$[127]$} \\
\hline $\begin{array}{r}\text { Chickpea (Cicer } \\
\text { arientinum L.) }\end{array}$ & Sodium silicate & Soil culture & $\begin{array}{l}\text { Growth attributes } \\
\text { Leaf relative water content (LRWC, \%) } \\
\mathrm{H}_{2} \mathrm{O}_{2} \text {, proline, MDA and lipoxygenase activities } \\
\text { Ascorbate peroxidase activity (APX) } \\
\text { SOD and CAT activity } \\
\text { Non-enzymatic activities }\end{array}$ & $\begin{array}{l}+ \\
+ \\
- \\
- \\
+ \\
+\end{array}$ & {$[111]$} \\
\hline $\begin{array}{l}\text { Sunflower (Helianthus } \\
\text { annuus L.) }\end{array}$ & Calcium silicate & Soil culture & $\begin{array}{l}\text { Morphological traits } \\
\text { Biomass } \\
\text { Leaf relative water content (LRWC, \%), } \\
\text { Stomatal resistance } \\
\text { Lipid peroxidation (MDA), Membrane permeability } \\
\quad \text { (EC, \%), proline and } \mathrm{H}_{2} \mathrm{O}_{2} \text { content } \\
\text { SOD and APx activity } \\
\text { Non-enzymatic activities }\end{array}$ & $\begin{array}{l}- \\
+ \\
+\end{array}$ & {$[128]$} \\
\hline $\begin{array}{l}\text { Canola (Brassica napus } \\
\text { L.) }\end{array}$ & Sodium silicate & Soil culture & $\begin{array}{l}\text { Growth/ biomass } \\
\text { Relative growth rate (RGR) and net assimilation rate } \\
\quad \text { (NAR) } \\
\text { Leaf water content } \mathrm{LWC}, \%) \\
\text { Photosynthesis }\left(P_{N}\right) \\
\text { Intracellular } \mathrm{CO}_{2} \text { level }(\mathrm{Ci}) \\
\text { Amino acids (roots) } \\
\text { Antioxidant enzymes } \\
\text { MDA content } \\
\text { Water uptake }\end{array}$ & $\begin{array}{l}+ \\
+ \\
+ \\
+ \\
- \\
+ \\
+ \\
\text { no } \\
+ \\
+\end{array}$ & [129] \\
\hline Rye (Secale cereal L.) & Potassium silicate & Soil culture & $\begin{array}{l}\text { Biomass } \\
\text { Shoot/ root ratio } \\
\text { Leaf photosynthetic efficiency }\left(P_{N}, E, g s\right) \\
\text { Water use efficiency (WUE) } \\
\text { Leaf water potential }\end{array}$ & $\begin{array}{l}+ \\
- \\
+ \\
+ \\
+\end{array}$ & {$[130]$} \\
\hline $\begin{array}{l}\text { Mango (Mangifera indica } \\
\text { L.) }\end{array}$ & Potassium silicate & Soil culture & $\begin{array}{l}\text { Growth traits } \\
\text { Auxins, gibberellins (GAs) and cytokinins (CKs) level } \\
\text { Abscisic acid (ABA) } \\
\text { CAT, POD and SOD level } \\
\text { Fruit quality }\end{array}$ & $\begin{array}{l}+ \\
+ \\
- \\
- \\
+\end{array}$ & {$[131]$} \\
\hline Zygophyllum xanthoxylum & Potassium silicate & $\begin{array}{l}\text { Soil/ sand } \\
\text { culture }\end{array}$ & $\begin{array}{l}\text { Growth/ plant development } \\
\text { CAT, POX and SOD activities } \\
\text { MDA, proline and soluble sugar content } \\
\text { Leaf water content (RWC, \%) } \\
\text { Photosynthetic activities/pigments }\left(P_{N}, E, g s, \mathrm{Chl} \mathrm{a}, \mathrm{b}\right. \\
\quad \& \mathrm{a}+\mathrm{b})\end{array}$ & $\begin{array}{l}+ \\
+ \\
- \\
+ \\
+\end{array}$ & [40] \\
\hline $\begin{array}{l}\text { Cucumber (Cucumis } \\
\text { sativus L.) }\end{array}$ & Sodium silicate & Soil culture & $\begin{array}{l}\text { Growth/ biomass parameters } \\
\text { Photosynthetic responses } \\
\text { Leaf water status } \\
\text { Chlorophyll content } \\
\text { Water holding capacity (WHC, \%) } \\
\text { Enzymatic activities }\end{array}$ & $\begin{array}{l}+ \\
+ \\
+ \\
+ \\
+ \\
+\end{array}$ & {$[132]$} \\
\hline & Potassium silicate & Soil culture & Biomass & + & [132] \\
\hline
\end{tabular}


Table 2 (continued)

\begin{tabular}{|c|c|c|c|c|c|}
\hline Plants & Source of $\mathrm{Si}$ & $\begin{array}{l}\text { Treatment } \\
\text { condition }\end{array}$ & Variables & Response & Reference \\
\hline $\begin{array}{l}\text { Alfalfa (Medicago sativa } \\
\text { L.) }\end{array}$ & & & $\begin{array}{l}\text { Cumulative WUE } \\
\text { Photosynthetic rate }\left(P_{N}\right) \\
\text { Stomatal conductance and transpiration rate (gs \& E) } \\
\text { Silicon level (shoot \& root) }\end{array}$ & $\begin{array}{l}+ \\
\text { No effect } \\
- \\
+\end{array}$ & \\
\hline $\begin{array}{l}\text { Kentucky Bluegrass (Poa } \\
\text { pratensis L.) }\end{array}$ & Sodium silicate & Soil culture & $\begin{array}{l}\text { Morpho-physiological traits } \\
\text { Photosynthetic performance }\left(P_{N}, E, g s\right) \\
\text { Relative leaf water content (RLWC, \%) } \\
\text { Leaf relative growth rate (RGR) } \\
\text { Water use efficiency (WUE) } \\
\text { Turf quality } \\
\text { Root/ shoot and leaf C/N ration }\end{array}$ & $\begin{array}{l}+ \\
+ \\
+ \\
+ \\
+ \\
+ \\
+\end{array}$ & [39] \\
\hline $\begin{array}{l}\text { Pepper (Capsicum } \\
\text { annuum L.) }\end{array}$ & Sodium silicate & Soil culture & $\begin{array}{l}\text { Growth traits } \\
\text { Photosynthetic activities }\left(P_{N}, E, g s\right) \\
\text { Proline content } \\
\text { Glycinebetaine level } \\
\text { Nitrate reductase activity (NR) } \\
\text { Total soluble protein and amino acids } \\
\text { Water relations } \\
\text { Nitrogen compounds }\end{array}$ & $\begin{array}{l}+ \\
+ \\
+ \\
+ \\
+ \\
+ \\
+ \\
+\end{array}$ & [37] \\
\hline $\begin{array}{l}\text { Sugarcane (Saccharum } \\
\text { officinarum L.) }\end{array}$ & Calcum-metasilicate & Soil culture & $\begin{array}{l}\text { Growth/ biomass traits } \\
\text { Leaf no./area expansion (LA/ LAE), } \\
\text { Leaf relative water content (LRWC, \%) } \\
\text { Leaf ultrastructures } \\
\text { Photosynthetic efficiency }\left(P_{N}, E, g s\right) \\
\text { Diurnal/ leaf position photosynthetic performance } \\
\text { Chlorophyll content/ index (Chl a, b, a+b \& SPAD } \\
\text { units) } \\
\text { Enzymatic activities } \\
\text { Non-enzymatic activities } \\
\text { Phyto-hormones }\end{array}$ & $\begin{array}{l}+ \\
+ \\
+ \\
+\end{array}$ & $\begin{array}{r}{[2,3,34} \\
41,58]\end{array}$ \\
\hline
\end{tabular}

Note: '+' increase and '-' decrease activity

plants [2, 25, 42]. In various crops, i.e. chickpea, sunflower, soybean, rice and sugarcane, the Si-mediated reduction in lipid peroxidation damage during drought $[41,74,92,111]$.

The enhancement of GR activity could lead to the upregulated level of GSH [64]. Loss of phospholipase activity in Si-applied plants during water stress indicates downregulation of phospholipid de-esterification damage in stressed plants [25, 112]. The CAT and POD activities were stimulated and the SOD activity decreased during water stress in Glycine max plants, while their activities and levels of $\mathrm{H}_{2} \mathrm{O}_{2}$ were all reduced by $\mathrm{Si}$ [92]. The impacts of $\mathrm{Si}$ on SOD and CAT activities were plant species dependent [85, 101]. ROS is central to cell signaling and affects a broad range of essential and cascading processes, like gene expression, growth, programmed cell death and a suite of stress responses $[110,113]$. Therefore, it is no surprise that down-regulation of ROS with the Si application results in different downstream changes during unfavorable situations $[9,13,101,114-116]$. Differences in regulatory positions can be intertwined with plant cultivars and circumstances of stress.

Overall, it can be concluded that $\mathrm{Si}$ can reduce oxidative damage in crop plants by regulating enzymatic and nonenzymatic antioxidant protection systems on the basis of the available findings $[8,41,108]$. Therefore, understanding the mechanisms that regulate stressed ROS signaling at the cellular level will provide a more successful strategy for improving resistance to extreme water-stressed conditions. To explain how silicon starts these responses, further studies are also needed. In addition, different results are obtained from studies of the floating water system, and thus further demonstrations are needed during the cultivation of agro-farming systems. 


\section{Silicon and the Regulation of Plant Hormones}

Plant hormones play a crucial role in the ability of plants to acclimatize by different mechanisms/functions to unfavorable environmental conditions. In the literature, they are often regarded as plant growth hormones [117]. Various phytohormones such as abscisic acid (ABA), indole acetic acid (IAA), salicylic acid (SA), brassinosteroids (BR), cytokinins (CKs), ethylene (ETH), gibberellic acid (GA) and jasmonic acid (JA) have been documented to stimulate plant performance in a coordinated fashion by either acting locally or being transported to another location within the plant $[9,101,118,119]$. Plant stress-related hormones plays an important role in mitigating plant responses to environmental stresses by which plants attempt to escape or withstand stressful situations and in doing so exhibit decreased plant growth so that the plant can concrete its resources on resisting stress. Very little information has been received to date on the influence of exogenous $\mathrm{Si}$ on endogenous plant hormone levels and their interaction with stimulatory silicon effects on plants, and only in recent years have some studies on this subject been released. According to Pei et al. [64] also demonstrated that Si enhanced ABA level in Triticum aestivum leaves cultivated under drought stressed condition (Fig. 1 and Table 1).

Silicon may increase the plant adaptation to water deficit by balancing the plant hormones levels [101, 120]. Silicon has maintained/enhanced the water stress resistance of sorghum by altering polyamine and 1-aminocyclopropane-1-carboxylic acid (ACC) synthesis [44]. Similar findings have been observed regarding the function of $\mathrm{Si}$ in promoting cytokinin biosynthesis and its involvement in leaf delay in arabidopsis and sorghum plants [116, 121]. Yin et al. [65] showed that $\mathrm{Si}$ increased the resistance of water-stress in sorghum plants by interfering with the equilibrium between polyamines and the content of ethylene. The upregulated content of polyamines in favor of low output of ethylene and decreased ACC level in sorghum plants, thereby delaying the process of leaf senescence and improving water deficit avoidance [44, 77].

In summary, the published reports point to silicon's role in stimulating the endogenous content of some plant hormones during environmental stresses. The research results mentioned are still limited, however, and evidence of a direct involvement between $\mathrm{Si}$ and biosynthesis of plant hormones is currently unavailable. Further research is therefore required to resolve the potential effects of Si on further phytohormones, while also concentrating on the physio-biochemical role of $\mathrm{Si}$, hormone biosynthesis, and hormone signaling of plants under water stress.

\section{Conclusion and Perspectives}

The application of silicon appears potentially significant to enhance crop productivity linked with agro-industries may be an enormous challenge for near future to feed the people globally with ecofriendly ecosystem with improve sustainable agricultural crop efficiency/ carbon transformation into the precisions food for future under limited water availability in arid and semi-arid agro-climatic zones worldwide.

Acknowledgments We are grateful to the Guangxi Academy of Agricultural Sciences, Nanning, Guangxi, China for providing the necessary facilities for this experiment.

Availability of Data All the supporting data/ findings of this study is available within the article.

Authors' Contributions KK Verma, XP Song and YR Li design the article. KK Verma, XP Song, B Lin, DJ Guo, VD Rajput, RK Singh, P Singh, A Sharma and MK Malviya performed the literature search and data analysis. The original draft of the manuscript was written by KK Verma and XP Song. M Singh, GL Chen and YR Li critically revised the manuscript. All authors read and approved the final manuscript.

Funding This study was financially supported by the Youth Program of National Natural Science Foundation of China (31901594), Fund for Guangxi Innovation Teams of Modern Agriculture Technology (gjnytxgxcxtd-03-01), Fund of Guangxi Academy of Agricultural Sciences (2021YT011) and Guangxi R and D Program Fund (GK17195100).

\section{Declarations}

Conflict of Interest None of the authors has any financial or other relationships that could lead to a conflict of interest.

Consent to Participate Not applicable.

Consent for Publication Not applicable.

\section{References}

1. Eneji AE, Inanaga S, Muranaka S, Li J, Hattori T, An P, Tsuji W (2008) Growth and nutrient use in four grasses under drought stress as mediated by silicon fertilizers. J Plant Nutr 31:355-365

2. Verma KK, Singh P, Song XP, Malviya MK, Singh RK, Chen GL, Solomon S, Li YR (2020) Mitigating climate change for sugarcane improvement: role of silicon in alleviating abiotic stresses. Sugar Tech 22:741-749

3. Verma KK, Liu XH, Wu KC, Singh RK, Song QQ, Malviya MK, Song XP, Singh P, Verma CL, Li YR (2020a) The impact of silicon on photosynthetic and biochemical responses of sugarcane under different soil moisture levels. Silicon 12:1355-1367

4. Bodner G, Nakhforoosh A, Kaul H-P (2015) Management of crop water under drought: a review. Agro Sust Develop 35:401-442

5. Shah F, Wu W (2019) Soil and crop management strategies to ensure higher crop productivity within sustainable environments. Sustainability 11:1485. https://doi.org/10.3390/su1 1051485

6. Cooke J, Leishman MR (2016) Consistent alleviation of abiotic stress with silicon addition: a meta-analysis. Funct Ecol 30:1340 1357

7. Richmond KE, Sussman M (2003) Got silicon? The non-essential beneficial plant nutrient. Curr Opinion Plant Biol 6:268-272 
8. Zhu Y, Gong H (2014) Beneficial effects of silicon on salt and drought tolerance in plants. Agron Sustain Dev 34:455-472

9. Thorne SJ, Hartley SE, Maathuis FJM (2020) Is silicon a panacea for alleviating drought and salt stress in crops? Front Plant Sci 11: 1221. https://doi.org/10.3389/fpls.2020.01221

10. Epstein E (1994) The anomaly of silicon in plant biology. Proc Natl Acad Sci U S A 91:11-17

11. Epstein E (1999) Silicon. Annu Rev Plant Physiol Plant Mol Biol 50:641-664

12. Epstein E (2009) Silicon: its manifold roles in plants. Ann Applied Biol 155:155-160

13. Liang Y, Nikolic M, Belanger R, Gong H, Song A (2015) Silicon in agriculture: from theory to practice. Springer, Dordrecht

14. van der Ploeg R, Bohm W, Kirkham M (1999) On the origin of the theory of mineral nutrition of plants and the law of the minimum. Soil Sci Soc Am J 63:1055-1062

15. Arnon DI, Stout PR (1939) The essentiality of certain elements in minute quantity for plants with special reference to copper. Plant Physiol 14:371-375

16. Gregoire C, Remus-Borel W, Vivancos J, Labbe C, Belzile F, Belanger RR (2012) Discovery of a multigene family of aquaporin silicon transporters in the primitive plant Equisetum arvense. Plant J 72:320-330

17. Vivancos J, Deshmukh R, Gregoire C, Remus-Borel W, Belzile F, Belanger RR (2016) Identification and characterization of silicon efflux transporters in horsetail (Equisetum arvense). J Plant Physiol 200:82-89

18. Liang YC, Ma TS, Li FJ, Feng YJ (1994) Silicon availability and response of rice and wheat to silicon in calcareous soils. Commun Soil Sci Plant Anal 25:2285-2297

19. Korndorfer GH, Lepsch I (2001) Effect of silicon on plant growth and crop yield. In: Datnoff LE, Snyder GH, Korndorfer GH (eds) Silicon in agriculture. Studies in plant science, vol 8. Elsevier, Amsterdam, pp 133-147

20. Guntzer F, Keller C, Meunier J-D (2012) Benefits of plant silicon for crops: a review. Agron Sustain Dev 32:201-213

21. Handreck KA, Jones LHP (1967) Uptake of monosilicic acid by Trifolium incarnatum. Aust J Biol Sci 20:483-486

22. Gong H, Blackmore D, Clingeleffer P, Sykes S, Jha D, Tester M, Walker R (2010) Contrast in chloride exclusion between two grapevine genotypes and its variation in their hybrid progeny. $\mathrm{J}$ Exp Bot 62:989-999

23. Khan A, Khan AL, Muneer S, Kim Y-H, Al-Rawahi A, AlHarrasi A (2019) Silicon and salinity: crosstalk in crop-mediated stress tolerance mechanisms. Front Plant Sc 10:1429. https://doi. org/10.3389/fpls.2019.01429

24. Ashraf M, Harris PJC (2013) Photosynthesis under stressful environments: an overview. Photosynthetica 51:163-190

25. Gong HJ, Zhu XY, Chen KM, Wang S, Zhang CL (2005) Silicon alleviates oxidative damage of wheat plants in pots under drought. Plant Sci 169:313-321

26. Hattori T, Inanaga S, Araki H, An P, Morita S, Luxová M, Lux A (2005) Application of silicon enhanced drought tolerance in Sorghum bicolour. Physiol Plant 123:459-466

27. Liu P, Yin L, Deng X, Wang S, Tanaka K, Zhang S (2014) Aquaporin-mediated increase in root hydraulic conductance is involved in silicon-induced improved root water uptake under osmotic stress in Sorghum bicolor L. J Exp Bot 65:4747-4756

28. Chen W, Yao XQ, Cai KZ, Chen J (2011) Silicon alleviates drought stress of rice plants by improving plant water status, photosynthesis and mineral nutrient absorption. Biol Trace Elem Res 142:67-76

29. Yordanov I, Velikova V, Tsonev T (2000) Plant responses to drought, acclimation, and stress tolerance. Photosynthetica 38: 171-186
30. Reddy AR, Chaitanya KV, Vivekanandanb M (2004) Droughtinduced responses of photosynthesis and antioxidant metabolism in higher plants. J Plant Physiol 161:1189-1202

31. Farooq M, Wahid A, Kobayashi N, Fujita D, Basra SMA (2009) Plant drought stress: effects, mechanisms and management. Agron Sustain Dev 29:185-212

32. Chen D, Wang S, Yin L, Deng X (2018) How does silicon mediate plant water uptake and loss under water deficiency? Front. Plant Sci 9:281. https://doi.org/10.3389/fpls.2018.00281

33. Gong H, Chen K (2012) The regulatory role of silicon on water relations, photosynthetic gas exchange, and carboxylation activities of wheat leaves in field drought conditions. Acta Physiol Plant 34:1589-1594

34. Verma KK, Song XP, Zeng Y, Li DM, Guo DJ, Rajput VD, Chen GL, Barakhov A, Minkina TM, Li YR (2020b) Characteristics of leaf stomata and their relationship with photosynthesis in Saccharum officinarum under drought and silicon application. ACS Omega 5(37):24145-24153

35. Ming DF (2012) Regulatory mechanisms of silicon on physiological and biochemical characteristics, ultrastructure and related gene expression of rice under water stress. $\mathrm{PhD}$ thesis, Zhejiang University, China

36. Sonobe K, Hattori T, An P, Tsuji W, Eneji AE, Kobayashi S, Kawamura Y, Tanaka K, Inanaga S (2011) Effect of silicon application on sorghum root responses to water stress. J Plant Nutr 34:71-82

37. Pereira TS, da Silva Lobato AK, Tan DKY, da Costa DV, Uchoa EB, Ferreira RDN, Pereira EDS, Avila FW, Marques DJ, Guedes EMS (2013) Positive interference of silicon on water relations, nitrogen metabolism, and osmotic adjustment in two pepper (Capsicum annuum) cultivars under water deficit. Aust J Crop Sci 7:1064-1071

38. Zhang C, Wang L, Zhang W, Zhang F (2013) Do lignification and silicification of the cell wall precede silicon deposition in the silica cell of the rice (Oryza sativa L.) leaf epidermis? Plant Soil 372: 137-149

39. Saud S, Li X, Chen Y, Zhang L, Fahad S, Hussain S, Sadiq A, Chen Y (2014) Silicon application increases drought tolerance of Kentucky bluegrass by improving plant water relations and morpho-physiological functions. Sci World J 2014:368694

40. Kang J, Zhao W, Zhu X (2016) Silicon improves photosynthesis and strengthens enzyme activities in the $\mathrm{C}_{3}$ succulent xerophyte Zygophyllum xanthoxylum under drought stress. J Plant Physiol 199:76-86

41. Verma KK, Wu KC, Singh P, Malviya MK, Singh RK, Song XP, Li YR (2019) The protective role of silicon in sugarcane under water stress: photosynthesis and antioxidant enzymes. Biomedical J Sci Tech Res 15(2):002685. https://doi.org/10.26717/BJSTR. 2019.15.002685

42. Verma KK, Song XP, Verma CL, Malviya MK, Guo DJ, Rajput VD, Sharma A, Wei KJ, Chen GL, Solomon S, Li YR (2021) Predication of photosynthetic leaf gas exchange of sugarcane (Saccharum spp.) leaves in response to leaf positions to foliar spray of potassium salt of active phosphorus under limited water irrigation. ACS Omega 6:2396-2409

43. Lobato AKS, Coimbra GK, Neto MAM, Costa RCL, Filho BGS, Neto CFO, Luz LM, Barreto AGT, Pereira BWF, Alves GAR, Monteiro BS, Marochio CA (2009) Protective action of silicon on ater relations and photosynthetic pigments in pepper plants induced to water deficit. Res J Biol Sci 4:617-623

44. Yin LN, Wang SW, Liu P, Wang WH, Cao D, Deng XP, Zhang SQ (2014) Silicon-mediated changes in polyamine and 1aminocyclopropane-1-carboxylic acid are involved in siliconinduced drought resistance in Sorghum bicolor L. Plant Physiol Biochem 80:268-277 
45. Aro E-M, McCaffery S, Anderson JM (1993) Photoinhibition and D1 protein degradation in peas acclimated to different growth irradiances. Plant Physiol 103:835-843

46. Shangguan ZP, Shao MA, Dyckmans J (2000) Effects of nitrogen nutrition and water deficit on net photosynthetic rate and chlorophyll fluorescence in winter wheat. J Plant Physiol 156:46-51

47. Adatia MH, Besford RT (1986) The effects of silicon on cucumber plants grown in recirculating nutrient solution. Ann Bot 58:343351

48. Doubnerova $\mathrm{V}$, Ryslava $\mathrm{H}$ (2011) What can enzymes of $\mathrm{C}_{4}$ photosynthesis do for $\mathrm{C}_{3}$ plants under stress? Plant Sci 180:575-583

49. Kaya C, Tuna L, Higgs D (2006) Effect of silicon on plant growth and mineral nutrition of maize grown under water-stress conditions. J Plant Nutr 29:1469-1480

50. Liang YC (1999) Effects of silicon on enzyme activity, and sodium, potassium and calcium concentration in barley under salt stress. Plant Soil 209:217-224

51. Detmann KC, Araújo L, Martins SCV, Sanglard LMVP, Reis JV, Detmann E, Rodrigues FA, Nunes-Nesi A, Fernie AR, DaMatta FM (2012) Silicon nutrition increases grain yield, which, in turn, exerts a feed-forward stimulation of photosynthetic rates via enhanced mesophyll conductance and alters primary metabolism in rice. New Phytol 196:752-762

52. Barber SA (1984) Soil nutrient bioavailability: a mechanistic approach. Wiley-Interscience Publication, New York

53. Ahmad ST, Haddad R (2011) Study of silicon effects on antioxidant enzyme activities and osmotic adjustment of wheat under drought stress. Czech J Genet Plant Breed 47:17-27

54. Hameed A, Sheikh MA, Jamil A, Basra SMA (2013) Seed priming with sodium silicate enhances seed germination and seedling growth in wheat (Triticum aestivum L.) under water deficit stress induced by polyethylene glycol. Pak J Life Soc Sci 11:19-24

55. Hattori T, Inanaga S, Tanimoto E, Lux A, Luxova M, Sugimoto Y (2003) Silicon-induced changes in viscoelastic properties of sorghum root cell walls. Plant Cell Physiol 44:743-749

56. Gupta B, Huang B (2014) Mechanism of salinity tolerance in plants: physiological, biochemical, and molecular characterization. Int J Genomics 2014:701596-701518. https://doi.org/10. 1155/2014/701596

57. Barber SA (1995) Soil nutrient bioavailability: a mechanistic approach. 2nd Edn. Wiley, New York

58. Verma KK, Singh RK, Song QQ, Singh P, Zhang BQ, Song XP, Chen GL, Li YR (2019a) Silicon alleviates drought stress of sugarcane plants by improving antioxidant responses. Biomed J Sci Tech Res MS ID 002957. https://doi.org/10.26717/BJSTR.2019. 17.002957

59. Maurel C, Chrispeels MJ (2001) Aquaporins. A molecular entry into plant water relations. Plant Physiol 125:135-138

60. Horie T, Kaneko T, Sugimoto G, Sasano S, Panda SK, Shibasaka M, Katsuhara M (2011) Mechanisms of water transport mediated by PIP aquaporins and their regulation via phosphorylation events under salinity stress in barley roots. Plant Cell Physiol 52:663-675

61. Luu DT, Maurel C (2005) Aquaporins in a challenging environment: molecular gears for adjusting plant water status. Plant Cell Environ 28:85-96

62. Verslues PE, Agarwal M, Katiyar-Agarwal S, Zhu J, Zhu JK (2006) Methods and concepts in quantifying resistance to drought, salt and freezing, abiotic stresses that affect plant water status. Plant J 45:523-539

63. Gong HJ, Chen KM, Zhao ZG, Chen GC, Zhou WJ (2008) Effects of silicon on defense of wheat against oxidative stress under drought at different developmental stages. Biol Plant 52:592-596

64. Pei ZF, Ming DF, Liu D, Wan GL, Geng XX, Gong HJ, Zhou WJ (2010) Silicon improves the tolerance to water-deficit stress induced by polyethylene glycol in wheat (Triticum aestivum L.) seedlings. J Plant Growth Regul 29:106-115
65. Yin LN, Wang SW, Li JY, Tanaka K, Oka M (2013) Application of silicon improves salt tolerance through ameliorating osmotic and ionic stresses in the seedling of Sorghum bicolor. Acta Physiol Plant 35:3099-3107. https://doi.org/10.1007/s11738013-1343-5

66. Liu P, Yin L, Wang S, Zhang M, Deng X, Zhang S, Tanaka K (2015) Enhanced root hydraulic conductance by aquaporin regulation accounts for silicon alleviated salt-induced osmotic stress in Sorghum bicolor L. Environ Exp Bot 111:42-51

67. Sutka M, Li G, Boudet J, Boursiac Y, Doumas P, Maurel C (2011) Natural variation of root hydraulics in Arabidopsis grown in normal and salt-stressed conditions. Plant Physiol 155:1264-1276

68. Shi Y, Zhang Y, Han W, Feng R, Hu Y, Guo J, Gong H (2016) Silicon enhances water stress tolerance by improving root hydraulic conductance in Solanum lycopersicum L. Front Plant Sci 7:196. https://doi.org/10.3389/fpls.2016.00196

69. Wang S, Liu P, Chen D, Yin L, Li H, Deng X (2015) Silicon enhanced salt tolerance by improving the root water uptake and decreasing the ion toxicity in cucumber. Front Plant Sci 6:759. https://doi.org/10.3389/fpls.2015.00759

70. Hattori T, Sonobe K, Inanaga S, An P, Morita S (2008b) Effects of silicon on photosynthesis of young cucumber seedlings under osmotic stress. J Plant Nutr 31:1046-1058

71. Gong HJ, Chen KM, Chen GC, Wang SM, Zhang CL (2003) Effects of silicon on growth of wheat under drought. J Plant Nutr 26:1055-1063

72. Hattori T, Sonobe K, Inanaga S, An P, Tsuji W, Araki H, Eneji AE, Morita S (2007) Short term stomatal responses to light intensity changes and osmotic stress in sorghum seedlings raised with and without silicon. Environ Exp Bot 60:177-182

73. Ogawa A, Yamauchi A (2006) Root osmotic adjustment under osmotic stress in maize seedlings 1. Transient change of growth and water relations in roots in response to osmotic stress. Plant Prod Sci 9:27-38

74. Ming DF, Yuan HM, Wang YH, Gong HJ, Zhou WJ (2012a) Effects of silicon on the physiological and biochemical characteristics of roots of rice seedlings under water stress. Sci Agric Sin 45:2510-2519

75. Ming DF, Pei ZF, Naeem MS, Gong HJ, Zhou WJ (2012b) Silicon alleviates PEG-induced water-defi cit stress in upland rice seedlings by enhancing osmotic adjustment. J Agron Crop Sci 198:14 26

76. Nayyar H, Walia DP (2003) Water stress induced proline accumulation in contrasting wheat genotypes as affected by calcium and abscisic acid. Biol Plant 46:275-279

77. Ali N, Schwarzenberg A, Yvin J-C, Hosseini SA (2018) Regulatory role of silicon in mediating differential stress tolerance responses in two contrasting tomato genotypes under osmotic stress. Front Plant Sci 9:1475. https://doi.org/10.3389/fpls.2018. 01475

78. Mansour MMF (1998) Protection of plasma membrane of onion epidermal cells by glycinebetaine and proline against $\mathrm{NaCl}$ stress. Plant Physiol Biochem 36:767-772

79. Parida AK, Das AB (2005) Salt tolerance and salinity effects on plants: a review. Ecotox Environ Saf 60:324-349

80. Lee SK, Sohn EY, Hamayun M, Yoon JY, Lee IJ (2010) Effect of silicon on growth and salinity stress of soybean plant grown under hydroponic system. Agrofor Syst 80:333-340

81. Torabi F, Majd A, Enteshari S (2015) The effect of silicon on alleviation of salt stress in borage (Borago officinalis L.). Soil Sci Plant Nutr 61:788-798

82. Hashemi A, Abdolzadeh A, Sadeghipour HR (2010) Benefi cial effects of silicon nutrition in alleviating salinity stress in hydroponically grown canola, Brassica napus L., plants. Soil Sci Plant Nutr 56:244-253 
83. Hajiboland R, Cherghvareh L, Dashtebani F (2016) Effect of silicon supplementation on wheat plants under salt stress. J Plant Proc Func 5:1-12

84. Maurel C, Verdoucq L, Luu DT, Santon V (2008) Plant aquaporins: membrane channels with multiple integrated functions. Annu Rev Plant Biol 59:595-624

85. Farooq MA, Dietz K-J (2015) Silicon as versatile player in plant and human biology: overlooked and poorly understood. Front Plant Sci 6:994. https://doi.org/10.3389/fpls.2015.00994

86. Bienert GB, Bienert MD, Jahn TP, Boutry M, Chaumont F (2011) Solanaceae XIPs are plasma membrane aquaporins that facilitate the transport of many uncharged substrates. Plant J 66:306-317

87. Fleck AT, Nye T, Repenning C, Stahl F, Zahn M, Schenk MK (2011) Silicon enhances suberization and lignification in roots of rice (Oryza sativa). J Exp Bot 62:2001-2011

88. Vaculík M, Landberg T, Greger M, Luxová M, Stoláriková LA (2012) Silicon modifies root anatomy, and uptake and subcellular distribution of cadmium in young maize plants. Ann Bot 110:433443

89. Maurel C, Boursiac Y, Luu DT, Santoni V, Shahzad Z, Verdoucq L (2015) Aquaporins in plants. Physiol Rev 95:1321-1358

90. Manivannan A, Ahn Y-K (2017) Silicon regulates potential genes involved in major physiological processes in plants to combat stress. Front Plant Sci 8:1346. https://doi.org/10.3389/fpls.2017. 01346

91. Agarie S, Hanaoka N, Ueno O, Miyazaki A, Kubota F, Agata W, Kaufman PB (1998) Effects of silicon on tolerance to water deficit and heat stress in rice plants (Oryza sativa L.), monitored by electrolyte leakage. Plant Prod Sci 1:96-103

92. Shen X, Zhou Y, Duan L, Li Z, Eneji AE, Li J (2010) Silicon effects on photosynthesis and antioxidant parameters of soybean seedlings under drought and ultraviolet-B radiation. J Plant Physiol 167:1248-1252

93. Ding YF (2006) Mechanisms of silicon-enhancement of drought tolerance in wheat seedlings. M.Sc. thesis, Nanjing Agricultural University, China

94. Huang Y, Yang F (1996) Physical state change of phospholipids mediated by $\mathrm{Ma} 2+$ modulates activity and conformation of reconstituted mitochondrial F0-F1-ATPase. In: Yang F, Wang F (eds) Membrane lipid-protein interaction andits application in medicine and agriculture. Shandong Science Press, Jinan, pp 1-17

95. Zhang W, Chen Q, Liu Y (2002) Relationship between $\mathrm{H}^{+}$ATPase activity and fluidity of tonoplast in barley roots under $\mathrm{NaCl}$ stress. Acta Bot Sin 44:292-296

96. Wang SY, Galletta GJ (1998) Foliar application of potassium silicate induces metabolic changes in strawberry plants. J Plant Nutr 21:157-167

97. Shinitzky M (1984) Membrane fluidity and cellular functions. In: Shinitzky M (ed) Physiology of membrane fluidity, vol 1. CRC Press, Boca Raton, pp 1-51

98. Muneer S, Park YG, Manivannan A, Soundararajan P, Jeong BR (2014) Physiological and proteomic analysis in chloroplasts of Solanum lycopersicum L. under silicon efficiency and salinity stress. Int J Mol Sci 15:21803-21824

99. Song A, Li P, Fan F, Li Z, Liang Y (2014) The effect of silicon on photosynthesis and expression of its relevant genes in rice (Oryza sativa L.) under high-zinc stress. PLoS One 9:e113782. https:// doi.org/10.1371/journal.pone. 0113782

100. Khattab HI, Emam MA, Emam MM, Helal NM, Mohamed MR (2014) Effect of selenium and silicon on transcription factors NAC5 and DREB2A involved in drought-responsive gene expression in rice. Biol Plant 58:265-273

101. Yin L, Wang S, Tanaka K, Fujihara S, Itai A, Den X, Zhang S (2016) Silicon mediated changes in polyamines participate in silicon-induced salt tolerance in Sorghum bicolor L. Plant Cell Environ 39:245-258
102. Li J, Leisner SM, Frantz J (2008) Alleviation of copper toxicity in Arabidopsis thaliana by silicon addition to hydroponic solutions. $\mathrm{J}$ Am Soc Horticult Sci 133:670-677

103. Liang YC, Zhang WH, Chen Q, Liu YL, Ding RX (2006) Effect of exogenous silicon $(\mathrm{Si})$ on $\mathrm{H}^{+}$-ATPase activity, phospholipids and fluidity of plasma membrane in leaves of salt-stressed barley (Hordeum vulgare L.). Environ Exp Bot 57:212-219

104. Schwarz K (1973) A bound form of silicon in glycosaminoglycans and polyuronides. Proc Natl Acad Sci U S A 70:1608-1612

105. Raven JA (1983) The transport and function of silicon in plants. Bio Rev Cambridge Philos Soc 58:179-207

106. Numan M, Bashir S, Khan Y, Mumtaz R, Shinwari ZK, Khan AL, Khan A, Al-Harrasi A (2018) Plant growth promoting bacteria as an alternative strategy for salt tolerance in plants: a review. Microbiol Res 209:21-32

107. Foyer CH (2018) Reactive oxygen species, oxidative signaling and the regulation of photosynthesis. Environ Exp Bot 154:134 142

108. Kim YH, Khan AL, Waqas M, Lee IJ (2017) Silicon regulates antioxidant activities of crop plants under abiotic-induced oxidative stress: a review. Front Plant Sci 8:510

109. Schmidt RE, Zhang X, Chalmers DR (1999) Response of photosynthesis andsuperoxide dismutase to silica applied to creeping bentgrass grown under two fertility levels. J Plant Nutr 22:17631773

110. Gill SS, Tuteja N (2010) Reactive oxygen species and antioxidant machinery in abiotic stress tolerance in crop plants. Plant Physiol Biochem 48:909-930

111. Gunes A, Pilbeam DJ, Inal A, Bagci EG, Coban S (2007) Influence of silicon on antioxidant mechanisms and lipid peroxidation in chickpea (Cicer arietinum L.) cultivars under drought stress. J Plant Interact 2:105-113

112. Abdel Latef AA, Tran L-SP (2016) Impacts of priming with silicon on the growth and tolerance of maize plants to alkaline stress. Front Plant Sci 7:243. https://doi.org/10.3389/fpls.2016.00243

113. Mittler R (2002) Oxidative stress, antioxidants and stress tolerance. Trends Plant Sci 7:405-410

114. Liang YC, Zhang WH, Chen Q, Ding RX (2005) Effects of silicon on $\mathrm{H}^{+}$-ATPase and $\mathrm{H}^{+}$-PPase activity, fatty acid composition and fluidity of tonoplast vesicles from roots of salt-stressed barley (Hordeum vulgare L.). Environ Exp Bot 53:29-37

115. Zhu ZJ, Wei GQ, Li J, Qian QQ, Yu JQ (2004) Silicon alleviates salt stress and increases antioxidant enzymes activity in leaves of salt-stressed cucumber (Cucumis sativus L.). Plant Sci 167:527533

116. Markovich O, Steiner E, Kouril S, Tarkowski P, Aharoni A, Elbaum R (2017) Silicon promotes cytokinin biosynthesis and delays senescence in Arabidopsis and sorghum. Plant Cell Environ 40:1189-1196

117. Peleg Z, Blumwald E (2011) Hormone balance and abiotic stress tolerance in crop plants. Curr Opin Plant Biol 14:290-295

118. Iqbal N, Umar S, Khan NA, Khan MIR (2014) A new perspective of phytohormones in salinity tolerance: regulation of proline metabolism. Environ Exp Bot 100:34 42

119. Fahad S, Hussain S, Matloob A, Khan FA, Khaliq A, Saud S, Hassan S, Shan D, Khan F, Ullah N (2015) Phytohormones and plant responses to salinity stress: a review. Plant Growth Regul 75: 391-404

120. Kim YH, Khan AL, Waqas M, Jeong HJ, Kim DH, Shin JS, Kim JG, Yeon MH, Lee IJ (2014) Regulation of jasmonic acid biosynthesis by silicon application during physical injury to Oryza sativa L. J Plant Res 127:525-532

121. Coskun D, Deshmukh R, Sonah H, Menzies JG, Reynolds O, Ma JF, Kronzucker HJ, Belanger RR (2019) The controversies of silicon's role in plant biology. New Phytol 221:67-85 
122. Ahmed M, Asif M, Hassan F (2014) Augmenting drought tolerance in sorghum by silicon nutrition. Acta Physiol Plant 36:473483

123. Safoora D, Cyrus G, Bahram B, Mahdi G, Siamak S (2018) Effect of silicon on growth and development of strawberry under water deficit conditions. Hort Plant J 4:226-232

124. Amin A, Ahmad R, Basra SMA, Murtaza G (2014) Silicon induced improvement in morpho-physiological traits of maize (Zea Mays L.) under water deficit. Pak J Agric Sci 51:187-196

125. Amin M, Ahmad R, Ali A, Hussain I, Mahmood R, Aslam M, Lee DJ (2018) Influence of silicon fertilization on maize performance under limited water supply. Silicon 10:177-183

126. Maghsoudi K, Emam Y, Ashraf M (2015) Influence of foliar application of silicon on chlorophyll fluorescence, photosynthetic pigments, and growth in water-stressed wheat cultivars differing in drought tolerance. Turk J Bot 39:625-634

127. Mauad M, Crusciol CAC, Nascente AS, Filho HG, Lima GPP (2016) Effects of silicon and drought stress on biochemical characteristics of leaves of upland rice cultivars. Revista Ciencia Agronomica 47:532-539
128. Gunes A, Pilbeam DJ, Inal A, Coban S (2008) Influence of silicon on sunflower cultivars under drought stress, I: growth, antioxidant mechanisms, and lipid peroxidation. Commun Soil Sci Plant Anal 39:1885-1903

129. Habibi G (2014) Silicon supplementation improves drought tolerance in canola plants. Russ J Plant Physiol 61:784-791

130. Hattori T, Ishii K, An P, Inanaga S (2009) Growth enhancement of rye by silicon application under two different soil water regimes. $\mathrm{J}$ Plant Nutr 32:187-196

131. Helaly MN, El-Hoseiny H, El-Sheery NI, Rastogi A, Kalaji HM (2017) Regulation and physiological role of silicon in alleviating drought stress of mango. Plant Physiol Biochem 118:31-44

132. Ma JF (2004) Role of silicon in enhancing the resistance of plants to biotic and abiotic stresses. Soil Sci Plant Nutr 50:11-18

Publisher's Note Springer Nature remains neutral with regard to jurisdictional claims in published maps and institutional affiliations. 